\title{
ADVANCED REGENERATIVE ENVIRONMENTAL CONTROL AND LIFE SUPPORT SYSTEMS: AIR AND WATER REGENERATION
}

\author{
F.H. Schubert, R.A. Wynveen, and P.D. Quattrone ** \\ *Life Systems, Inc., 24755 Highpoint Road, Cleveland, OH 44122, U.S.A., \\ **NASA Ames Research Center, Moffett Field, CA, U.S.A.
}

\section{ABSTRACT}

Extended manned space missions will require regenerative life support techniques. Past U.S. manned missions used nonregenerative expendables, except for a molecular sieve-based carbon dioxide removal system aboard Skylab. The resupply penalties associated with expendables becomes prohibitive as crew size and mission duration increase. The U.S. Space Station. scheduled to be operational in the 1990's, is based on a crew of four to sixteen and a resupply period of 90 days or greater. It will be the first major spacecratt to employ regenerable techniques for life support. The paper uses the requirements for the Space Station to address these techniques.

\section{INTRODUCTION}

The need and requirements tor a low earth orbit Space Station have been studied and detined. It will provide for the U.S. and other tree world countries a comprehensive capability to exploit and explore the space environment. It will support and be part of a wide range of missions with objectives in science. applications. commercial activities and technology development. The Space Station will evoive by time-phased modular increments delivered and supplied by the Space Shuttle /1,2/. It will be capable of operating continuously manned and. under special circumstances. unmanned. A minimum useful lifetime of ten years is sought. but life cycle costs decrease continuously as the operating life increases beyond this minimum level

\section{SPACE STATION SYSTEMS}

The Space Station has been divided into 13 systems $/ 1 /$. The current paper addresses just one of these: the Environmental Control/Life Support System (ECLSS)

\author{
Environmental Control/Life Support System \\ The ECLSS can be divided into six functional categories: \\ - Air Revitalization System \\ - Atmospheric Pressure and Composition Control System \\ - Cabin Temperature and Humidity Control System \\ - Water Reclamation System \\ - Personal Hygiene System \\ - Waste Management System
}

Each of these, in turn, are further subdivided, e.g., the Air Revitalization System into carbon dioxide $\left(\mathrm{CO}_{2}\right)$ concentration, $\mathrm{CO}_{2}$ reduction, oxygen $\left(\mathrm{O}_{2}\right)$ generation, trace contaminant control and atmosphere quality monitor. The tirst three functional categories makeup the Atmosphere Management Group. The last three makeup the Water and Waste Management Group. A third group could be considered those functional elements needed to provide a safe haven capability.

ECLSS Functions. Table 1 summarizes the ECLSS functions. The functions include, for example, providing $\mathrm{O}_{2}$ for metabolic consumption, Space Station leakage and airlock use. It is maintained or controlled by monitoring the partial pressure of $0_{2}$ $\left(\mathrm{pO}_{2}\right)$ in the atmosphere

ECLSS Performance Requirements. Table 2 summarizes the ECLSS pertarmance requirements $/ 3$ / being used on the Space Station studies. These requirements are close to those used for previous studies $/ 4-7 /$. These requirements are further supplemented by such needs as sutficient $\mathrm{O}_{2}$ and nitrogen $\left(\mathrm{N}_{2}\right)$ storage aboard the Space Station for one total emergency repressurization; atmospheric leakage to be less than $0.5 \mathrm{lb} /$ day

\section{TABLE 1 ECLSS Functions}

\begin{tabular}{|c|c|c|}
\hline Functions & Applications & $\begin{array}{l}\text { Maintain Or } \\
\text { Control }\end{array}$ \\
\hline - Provide $\mathrm{O}_{2}$ & - For Metabolic, Leakage. Airlock Use & $\mathrm{pO}_{2}$ \\
\hline - Provide $\mathrm{H}_{2} \mathrm{O}$ & - For Drinking. Cooking. Bathing, Dishes, Laundry & -- \\
\hline - Remove $\mathrm{CO}_{2}$ & - From Metabolic & $\mathrm{pCO}_{2}$ \\
\hline - Remove $\mathrm{H}_{2} \mathrm{O}$ & $\begin{array}{l}\text { - From Respiration, Perspiration, Use of Handwash, } \\
\text { Shower, and Washer/Dryer }\end{array}$ & $\mathrm{pH}_{2} \mathrm{O}(\mathrm{RH})$ \\
\hline - Remove Trace Contam. & - From Crew. Equipment. Outgassing & Trace Contarn. \\
\hline - Provide $\mathrm{N}_{2}$ & $\begin{array}{l}\text { - For Leakage, Airlock Use. Purging, Pressure } \\
\text { Reference }\end{array}$ & $\mathrm{O}_{2} / \mathrm{N}_{2}$ Ratio \\
\hline - Provide Environment & - Temperature, Pressure, Relative Humidity & $\mathrm{T}, \mathrm{P}$ \\
\hline - Provide Facilities & $\begin{array}{l}\text { - Handwash. Shower, Dishwasher, Clothes } \\
\text { Washer/Dryer. Toilet, Trash Compactor, } \\
\text { Air Ventilation/Filtration }\end{array}$ & -- \\
\hline - Provide Bacterial Control & - Of Air. Water, Waste Solids/Liquids & Bacteria \\
\hline
\end{tabular}


TABLE 2 ECLSS Performance Requirements

\begin{tabular}{|c|c|c|c|c|}
\hline PARAMETER & UNITS & OPERATIONAL & $\begin{array}{c}90 \cdot \text { DAY } \\
\text { DEGRADED }\end{array}$ & $\begin{array}{c}\text { 21-DAY } \\
\text { EMERGENCY }\end{array}$ \\
\hline $\mathrm{CO}_{i}$ Partial Pressure & $\mathrm{mmHg}$ & $3.0 \mathrm{Max}$. & 7.6 Max. & 12 Max. \\
\hline Temperature & $\operatorname{deg} F$ & $65-75$ & $60-85$ & $60-90$ \\
\hline Dew Point & $\operatorname{deg} F$ & $40-60$ & $35-70$ & $35-70$ \\
\hline Ventilation & $\mathrm{ft} / \mathrm{min}$ & $15-40$ & $10-100$ & $5-200$ \\
\hline Potable Water & Ib/man-day & $6.8-8.1$ & $6.8 \mathrm{~min}$ & $6.8 \mathrm{~min}$ \\
\hline Hygiene Water & tb/man-day & $12 \mathrm{~min}$ & $6 \mathrm{~min}$ & $3 \min$ \\
\hline Wash Water & ID/man.day & $28 \mathrm{~min}$ & $14 \mathrm{~min}$ & 0 \\
\hline $\mathrm{O}_{2}$ Partial Pressure ${ }^{31}$ & psia & $2.7-3.2$ & $2.4-3.8$ & $2.3-3.9$ \\
\hline Total Pressure & psia & 14.7 & $10-14.7$ & $10-14.7$ \\
\hline Trace Contaminants & - & $\begin{array}{l}24 \mathrm{hr} \text {. Ind. } \\
\text { Standard }\end{array}$ & $\begin{array}{l}8 \mathrm{hr} \text {. ind. } \\
\text { Standard }\end{array}$ & $\begin{array}{l}8 \mathrm{hr} \text {. Ind. } \\
\text { Standard }\end{array}$ \\
\hline Microbial Count & per $\mathrm{ft}^{3}$ & 100 & - & - \\
\hline Maximum Crew Member & Per Space Station & 8 & 8 & 12 \\
\hline Maximum Crew Member & Per Habitat Module & 4 & 8 & 8 \\
\hline
\end{tabular}

per module and $5 \mathrm{lb} /$ day for the entire Space Station; exposure of ECLSS equipment to cabin pressure of 0 to 10 psia must not create hazard of cause damage; etc.

ECLSS Average Design Loads. The ECLSS average design loads are given in Table $3 / 8 /$. Although similar to those used for previous studies, values often differ significantly in areas of importance to ECLSS designers.

\section{ECLSS CLOSURE OPTIONS}

Current state- of -the-art ECLSS is based on an expendable or "open loop" system approach. Various options exist for the space ECLSS designer to reduce the resupply requirements and costs associated with expendables. Options range from an enhanced open loop in which only regenerable $\mathrm{CO}_{2}$ removal is used to a completely closed ECLSS where lood is regenerated aboard the space vehicle.

\section{TABLE 3 ECLSS Design Average Loads}

\begin{tabular}{|c|c|c|}
\hline & $\begin{array}{c}\text { Space } \\
\text { Station Values } 181 \\
\end{array}$ & SOC Value 19 \\
\hline Metabolic $\mathrm{O}_{2}$ & $1.84 \mathrm{lb} / \mathrm{man}$ day & $\begin{array}{l}1.84 \mathrm{lb} / \text { man day } \\
5.00 \mathrm{lb} / \text { day tolat } 500\end{array}$ \\
\hline $\begin{array}{l}\text { Leakage } \mathrm{A}_{1 \mathrm{r}} \\
\mathrm{EVA} \mathrm{O}_{2}\end{array}$ & $1.32 \mathrm{lb} / 8 \mathrm{hr}$ EVA & $\begin{array}{l}5.00 \mathrm{lb} \text { /day tolal SOC } \\
1.22 \mathrm{lo} / 8 \mathrm{hr} \text { EVA }\end{array}$ \\
\hline $\mathrm{EVACO}_{2}$ & $1.67 \mathrm{lD} / 8 \mathrm{hr}$ EVA & $1.48 \mathrm{lb} / 8 \mathrm{hr}$ EVA \\
\hline Metabolic $\mathrm{CO}_{2}$ & $2.20 \mathrm{lb} / \mathrm{man}$ day & $2.20 \mathrm{lb} / \mathrm{man}$ day \\
\hline Drinking Water & $2.86 \mathrm{lb} / \mathrm{man}$ day & $4.09 \mathrm{lb} / \mathrm{man}$ day \\
\hline Food Preparatıon Water & $3.90 \mathrm{lb} /$ man day & $1.58 \mathrm{lb} / \mathrm{man}$ day \\
\hline Metabolic Water Production & $0.78 \mathrm{lb} / \mathrm{man}$ day & $0.70 \mathrm{lo} / \mathrm{man}$ day \\
\hline Cloltıng Wash Water & $27.50 \mathrm{lb} / \mathrm{man}$ day & $27.50 \mathrm{lb} / \mathrm{man}$ day \\
\hline Hand Wash Water & $7.00 \mathrm{lb} / \mathrm{man}$ day & $4.00 \mathrm{lb} / \mathrm{man}$ day \\
\hline Shower Water & $5.00 \mathrm{lb} /$ man day & $8.00 \mathrm{l} / \mathrm{man}$ day \\
\hline EVA Water & $9.68 \mathrm{lb} / 8 \mathrm{hr}$ EVA. & $9.68 \mathrm{lb} / 8 \mathrm{hr}$ EVÁ \\
\hline $\begin{array}{l}\text { Perspiration and Respiration } \\
\text { Water }\end{array}$ & $4.02 \mathrm{lb} /$ man day & $4.02 \mathrm{lb} / \mathrm{man}$ day \\
\hline Urinal Flush Water & $1.09 \mathrm{lb} /$ man day $\cdot(\mathrm{a})$ & $1.09 \mathrm{lb} /$ man day \\
\hline Urine Water & $3.31 \mathrm{ld} / \mathrm{man}$ day ${ }^{*}$ (a) & $3.31 \mathrm{l} / \mathrm{man}$ day \\
\hline Food Solids & $1.36 \mathrm{lb} / \mathrm{man}$ day & $1.60 \mathrm{l} / \mathrm{m}$ man day \\
\hline Food Water & $1.10 \mathrm{Ib} / \mathrm{m}$ an day & $1.00 \mathrm{lb} / \mathrm{m} a n$ day \\
\hline Food Packaging & $1.00 \mathrm{lb} / \mathrm{man}$ day ${ }^{\circ}$ & $1.00 \mathrm{lb} / \mathrm{man}$ day \\
\hline Urine Solias & $0.13 \mathrm{lb} / \mathrm{man}$ day & $0.13 \mathrm{lb} / \mathrm{man}$ day \\
\hline Fecal Solids & $0.07 \mathrm{lb} / \mathrm{man}$ day & $0.07 \mathrm{Ib} / \mathrm{man}$ day \\
\hline Sweat Solids & 0.04 tb/man day & $0.04 \mathrm{lb} / \mathrm{man}$ day \\
\hline EVA Wastewater & $2.00 \mathrm{lb} / 8 \mathrm{hr}$ EVA & $2.00 \mathrm{lb} / 8 \mathrm{hr}$ EVÁ \\
\hline Charcoal Required & $0.13 \mathrm{lb} / \mathrm{man}$ day & $0.13 \mathrm{lb} / \mathrm{man}$ day \\
\hline Metabolic Sensible Heat & $7.010 \mathrm{BTU} / \mathrm{man}$ day & 7,000 BTU/man day \\
\hline Hygiene Latent Water & $0.94 \mathrm{lb} / \mathrm{man}$ day & $0.94 \mathrm{lb} / \mathrm{man}$ day \\
\hline $\begin{array}{l}\text { Food Preparation Latent } \\
\text { Water }\end{array}$ & $0.06 \mathrm{lb} / \mathrm{man}$ day ${ }^{*}$ & $0.06 \mathrm{lb} / \mathrm{man}$ day \\
\hline Experiments Latent Water & $1.00 \mathrm{lb} / \mathrm{day}$ & $1.00 \mathrm{lb} / \mathrm{d} a \mathrm{y}$ \\
\hline Laundry Latent Water & $0.13 \mathrm{lb} / \mathrm{man}$ day & $0.13 \mathrm{lb} / \mathrm{man}$ day \\
\hline Waste Wash Water Solids & $0.44 \%$ & $0.44 \%$ \\
\hline Expended Water Solids ${ }^{|b|}$ & $0.13 \%$ & $0.13 \%$ \\
\hline Air Lock Gas Loss & $2.40 \mathrm{lb} / E V A$ & $2.40 \mathrm{lb} /$ use \\
\hline Trash & $1.80 \mathrm{lo} / \mathrm{man}$ day ${ }^{\circ}$ & $1.80 \mathrm{lb} / \mathrm{man}$ day \\
\hline Trash Volume & $0.10 \mathrm{ft} 3 / \mathrm{man}$ day ${ }^{*}$ & $0.10 \mathrm{ft} 3 / \mathrm{man}$ day \\
\hline
\end{tabular}

- Not cited in reference but taken from the Space Operations Center Study $19 \%$.

(a) Cited reference identified urine. at $4.4 \mathrm{lb} / \mathrm{man}$ day, approximately combined total of urinal flush water and urine water.

(b) Assumed shower and hand wash.

\section{Alternatives}

Cost-effective continuous operation of the Space Station requires use of some level of regenerative techniques. Table 4 presents a range of closure operations. Major ones include: a) Regenerable $\mathrm{CO}_{2}$ removal; b) Regeneration of $\mathrm{O}_{2} ; \mathrm{c}$ ) Reclamation of water and d) Regeneration of food. All of these are candidates for a 1990's in-orbit Space Station. Technology for closure of the food cycle, however, while currently under development, may not reach the maturity level needed to be a viable candidate when the initiation of the detailed Space Station design must start (projected 1987). Regeneration of $\mathrm{N}_{2}$ is not under development, but a subsystem for on-board generation of $\mathrm{N}_{2}$ from potential propellents (e.g., hydrazine, $\mathrm{N}_{2} \mathrm{H}_{4}$ ) is being developed.

\section{Open Loop Costs}

The launch weight of a Space Station decreases as the $\mathrm{CO}_{2}$ removal, water and $\mathrm{O}_{2}$ loops are closed. This is illustrated in Figure 1. The level of launch weight savings, however, can vary depending upon many factors. This is illustrated in Figure 2 which shows the impact on launch weight for the initial launch (with 120 days of on-board storage) and for resupply every 90 days as function of crew size. The results are presented for three different levels of water allotment:

- A minimum level defined as only the water required for drinking. food preparation, hand washing and urinal flushing

- An acceptable level defined as the minimum level plus adding the water for a full body shower

- A full service level defined as the acceptable levei plus adding the water for clothes washing and dish washing

The water requirements are based on the quantity of water per person day for the water uses cited in Table 5 . Note, the water requirements from Table 3 have been included. There are. however, many less visible, but yet expensive hidden costs of an open loop, expendable driven Space Station design. Some of these are cited in Table 6.

\section{AVAILABLE}

\section{REGENERABLE ECLSS TECHNIQUES ARE}

Regenerable techniques are available and developed, for example, to close the $\mathrm{CO}_{2}$ removal, $\mathrm{O}_{2}$ generation and water reclamation loops. The technologies for tood closure are under development.

\section{$\mathrm{CO}_{2}$ Removal}

Of the more than nine $\mathrm{CO}_{2}$ removal concepts evaluated by NASA, two techniques remain as viable candidates. They are the Electrochemical $\mathrm{CO}_{2}$ Concentrator, or EDC, and the Steam Desorbed Amine Subsystem (SDAS) / 10-12/. 
TABLE 4 Possible Degree of Closure Options
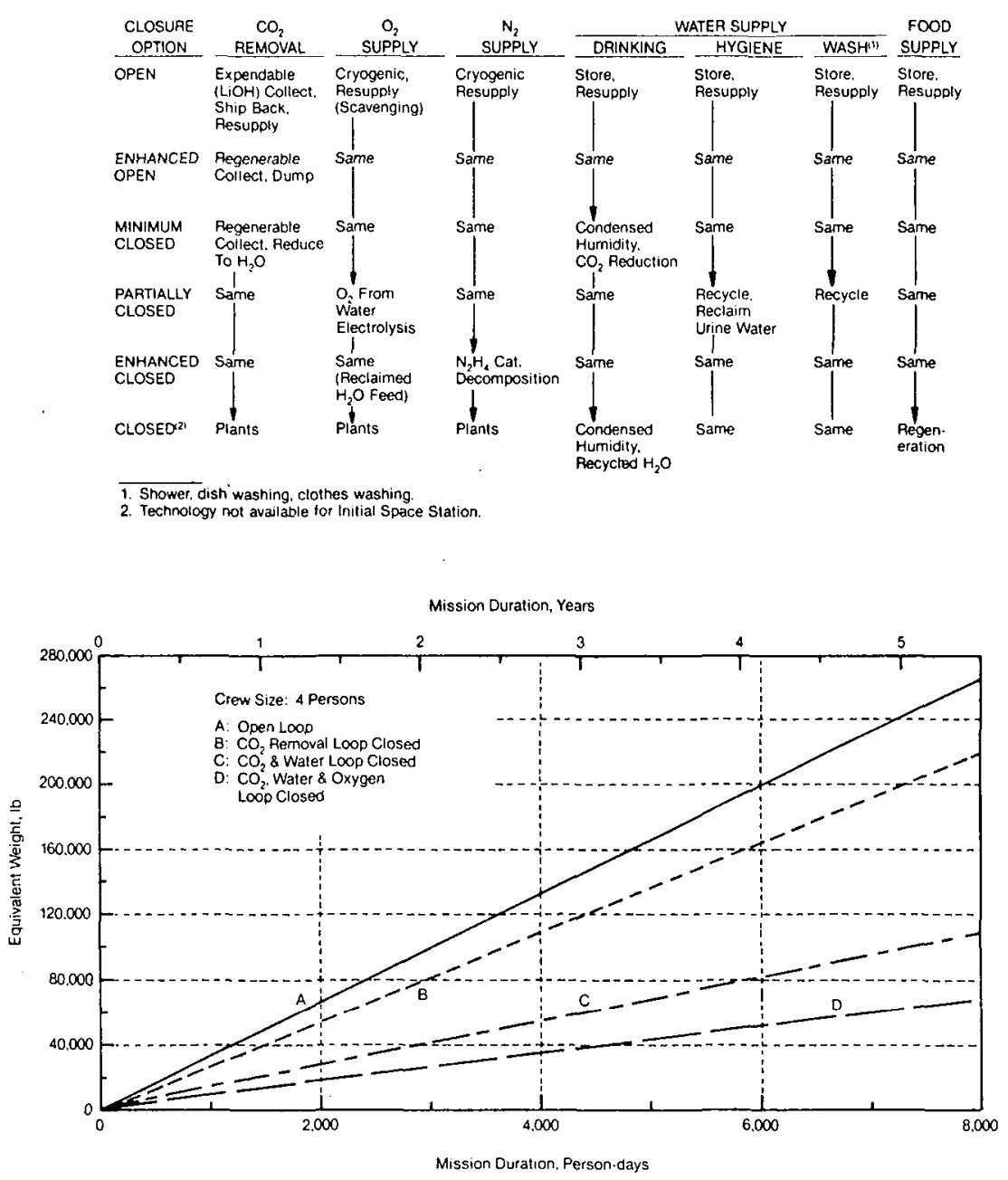

Fig. 1. Regenerative Versus Non-Regenerative ECLSS

\section{$\underline{\mathbf{O}_{2} \text { Regeneration }}$}

Regeneration of $\mathrm{O}_{2}$ requires the reduction of the concentrated $\mathrm{CO}_{2}$ with hydrogen $\left(\mathrm{H}_{2}\right)$ to form a carbon product and water. Electrolysis of the latter is then used to regenerate the $\mathrm{O}_{2}$ and simultaneously provide $\mathrm{H}_{2}$ for the reduction of $\mathrm{CO}_{2}$.

Two $\mathrm{CO}_{2}$ reduction techniques are being actively developed. One involves the reduction to form methane $\left(\mathrm{CH}_{4}\right)$ gas (Sabatier Process). The $\mathrm{CH}_{4}$ would then be vented overboard or be used in a resistojet for attitude control. The other is based on the reduction of $\mathrm{CO}_{2}$ to form carbon (Bosch Process). This would eliminate overboard venting since the carbon would periodically be returned to earth.

Two $\mathrm{O}_{2}$ (water electrolysis) generation techniques are being actively developed. One involves the static feed addition of water to the electrolysis cell (SFE) and uses an alkaline electrolyte. The other is based on a recirculating water feed system and is characterized by an electrolysis cell, which employs an acid electrolyte in a solid polymer form.

\section{Water Reclamation}

Two basic processes are being developed for recovering water. One is based upon phase change techniques, e.g., vapor compression and distillation. The other is based on filtration techniques, e.g., ultrafiltration and then reverse osmosis.

\section{Open Issues Impacting ECLSS Design}

Many issues impacting the ECLSS design remain to be resolved These include, for example: a) The technology readiness on the specific date the final Space Station design will be initiated; $b$ ) The level of extravehicular activity; $c$ ) The level of overboard venting to be allowed, and; d) The selected crew size. Many major technology gaps are associated with ECLSS, such as:

1. Regenerative techniques have not flown previously and therefore, have not reached the highest technology maturity level.

2. Quantitative failure rate data is missing which establishes reliability, defines spares and dictates maintainability approaches.

3. Integration of selected functions or subsystems are only beginning to be implemented.

4. Flight maintainable hardware designs are immature.

5. Fault diagnostic capabilities of instrumentation are limited. 


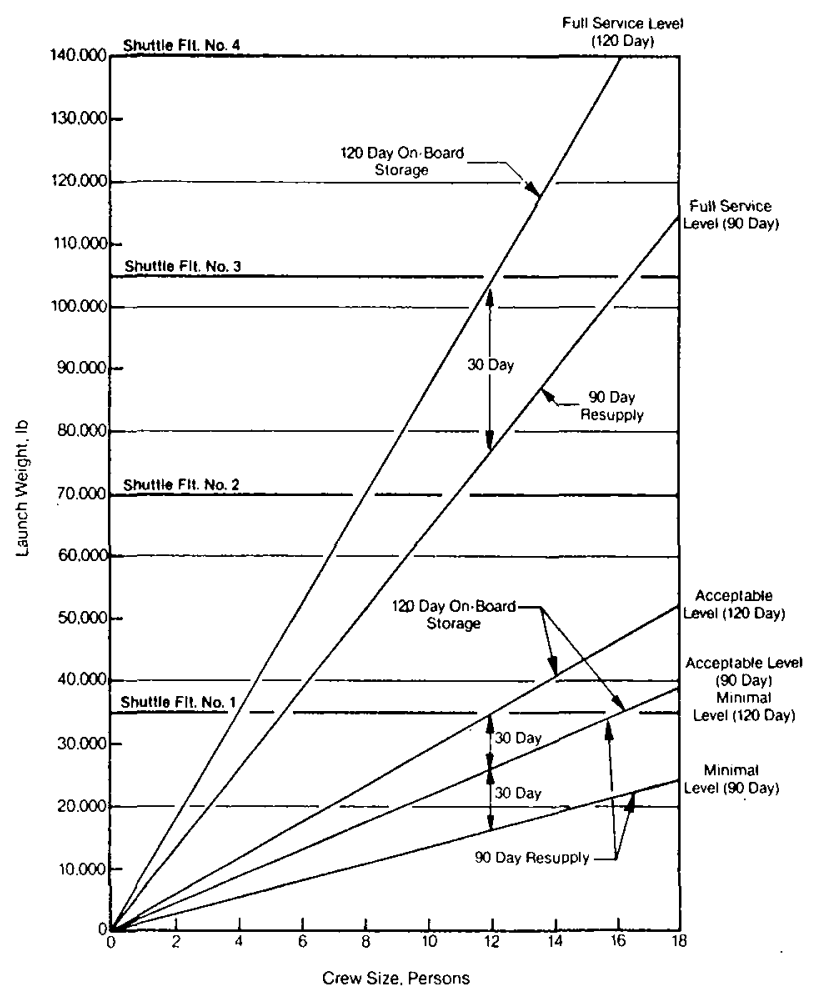

Fig. 2. Space Station ECLSS Block Diagram

TABLE 5 Water Needed: Resupplied or Reclaimed?

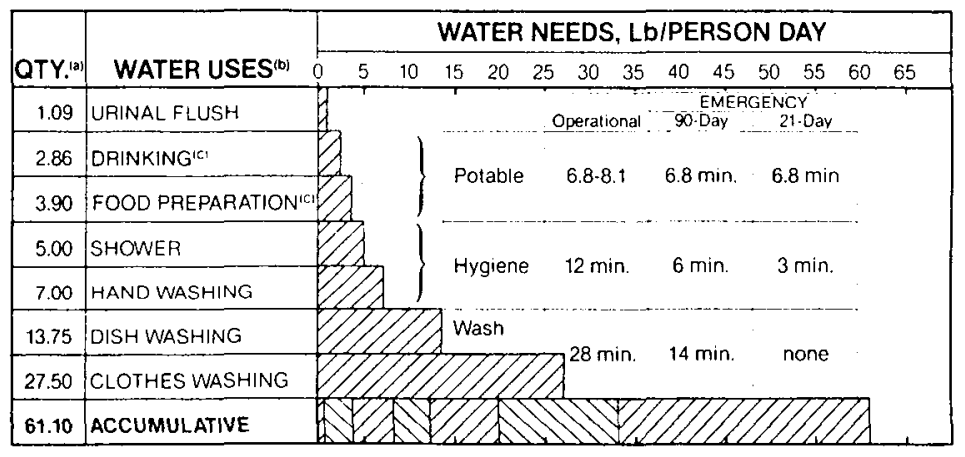

(a) Lo/Person-Day (unless nonventing thermal approach used).

(c) These water users require potable quality water.

TABLE 6 "Hidden" Costs of Expendable (0pen Loop) Operation

- More Frequent Resupply Flights

- Non-mission related work

- Wear and tear on launch vehicles

- Chance for major failure

- Lower In-Orbit Crew Productivity

- Expendable replacement time

- Resupply unloading time

- Spent expendable loading time

- Increased Logistics Costs

- Maintaining "supply lines"

- Maintaining inventory (and associated documentation)

- Maintaining waste disposal facilities

- High Retrofit Costs ${ }^{(a)}$

(a) Would probably not be implemented because of high cost, complexity, uncertainty and momentum. 


\section{REGENERATIVE ECLSS TECHNOLOGY}

Many regenerative ECLSS developments have been completed over the past 25 years. Major developments relating to air revitalization and water reclamation systems will now be reviewed. The Air Revitalization System alternatives are summarized in Table 7

\section{Regenerable $\mathrm{CO}_{2}$ Removal Concentration}

The EDC and SDAS processes have been described eisewhere 110-12\%. Table 8 presents a comparison of total equivalent weight of the EDC versus the SDAS. The EDC has evolved into a simpie low-cost. reliable and flexible system. It has been designed and

TABLE 7 Air Revitalization System Alternatives

\begin{tabular}{|c|c|c|c|}
\hline & & Alternatives & \\
\hline APS & Open & Closed & Techrotogies \\
\hline $\mathrm{CO}$, Removal & $\mathrm{LIOH}$ & Regenerative & $\begin{array}{l}\text { Electrocnemical } \\
\text { Solig Amine }\end{array}$ \\
\hline Co. Reduction & -- & To Yiela $\mathrm{HiO}$ & $\begin{array}{l}\text { Sabanter } \mathrm{CH}_{\text {i }} \\
\text { Bosen iCartons }\end{array}$ \\
\hline O. Supply & cryogenic & Electrolysis & $\begin{array}{l}\text { Static Feed iAlkaline! } \\
\text { Solid Polymer (Aciol }\end{array}$ \\
\hline Trace Comam. & $\begin{array}{l}\text { Active Carbon \& } \\
\text { Amb T Cat } 0 x\end{array}$ & $\begin{array}{l}\text { High Temp } \\
\text { Cat Oxidizer }\end{array}$ & $\begin{array}{l}\text { Expend Aosorvers } \\
\text { Regen Absorbers }\end{array}$ \\
\hline Alm Qual Mon & Yes & Yes & $\begin{array}{l}\text { Gas Chrom. } \\
\text { Mass Spec }\end{array}$ \\
\hline
\end{tabular}

TABLE 8 Total Equivalent Weight EDC Versus Steam-Desorbed Amine

\begin{tabular}{|c|c|c|c|c|}
\hline & Req & $\begin{array}{l}\text { Steam. } \\
\text { Desorbed } \\
\text { Amine }\end{array}$ & Total & $\begin{array}{l}\text { Equivalent } \\
\text { eqght: it } \\
\text { Sieam. } \\
\text { Desorbed } \\
\text { Amine }\end{array}$ \\
\hline Fixed Hardware Weight & & , & 86 & 139 \\
\hline $\begin{array}{l}\text { Power } \\
\text { Reguirements. W } \\
\text { AC } \\
\text { DC }\end{array}$ & $\begin{array}{l}150 \\
.97\end{array}$ & $\begin{array}{l}375 \\
526\end{array}$ & & \\
\hline Werght Penalty & & & 49 & 577 \\
\hline $\begin{array}{l}\text { Heat Rejection } \\
\text { Requirements. W } \\
\text { To Alr } \\
\text { To Liquid }\end{array}$ & $\begin{array}{l}277 \\
128\end{array}$ & $\begin{array}{c}901 \\
-\end{array}$ & & \\
\hline Werght Penalty & & & 145 & 394 \\
\hline Subtotal Equivalent Weight & & & 280 & $1.110^{\circ}$ \\
\hline $\begin{array}{l}\text { Assoc. Subsystem Penalties'it } \\
\text { Humidity Control } \\
\text { Water. ID:day } \\
\text { Weight Penalty }\end{array}$ & 4 & 32 & 102 & 770 \\
\hline $\begin{array}{l}\text { Water Processing } \\
\text { Water. IbIday } \\
\text { Weight Penalty }\end{array}$ & 4 & 32 & 27 & 206 \\
\hline $\begin{array}{l}\text { O. Generation (H.O. Ib/day) } \\
\text { Water, tb:day } \\
\text { Weight Penalty }\end{array}$ & 4 & & 309 & \\
\hline Total Equivalent Weight & & & 718 & $2.086 心$ \\
\hline
\end{tabular}

(a) Including nardware, power and heat load penatties.

(b) Amine is 36 umes greater equivalent weignu inan EDC (c) Amine is 29 limes greater equivalent weign: than EDC

tested for Space Station and Shuttle Orbiter missions. Currently more than 20.000 hours have been accumulated on an EDC module under just one endurance / performance test program. Table 9 presents the size of the EDC for Space Stations with crew sizes of 4. 6.8 and 12. Figure 3 shows the four-person hardware (CS-4). The size is shown in Table 9 under Model CS -4

The EDC offers many advantages over other regenerable $\mathrm{CO}_{2}$ removal processes:

1. A lower equivalent weight which becomes more significant as the partial pressure of $\mathrm{CO}_{2}$ decreases (see Figure 4) $/ 13 /$.

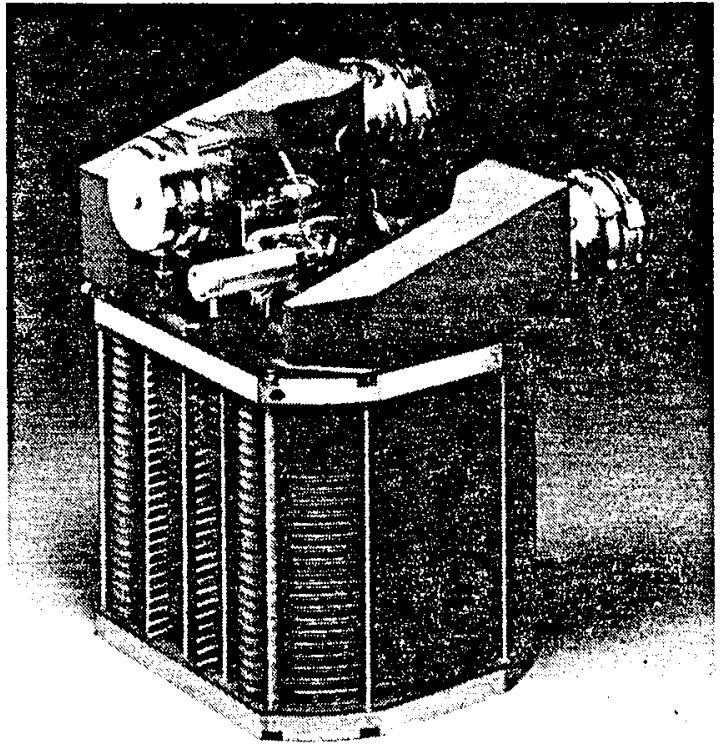

Fig. 3. Electrochemical $\mathrm{CO}_{2}$ Removal Subsystem. Four-Person Capacity

2. Readily adapts to varying crew sizes snce only cells are added or deleted rather than developing completely ne:w canisters for each change in crew size.

3. Avoids the large atmosphere humidity load which is a byproduct of the SDAS

4. Operates continuously or cyclically for user flexibility. rather than only cyclically as characteristic of the SDAS.

5. Premixes the $\mathrm{H}$, and $\mathrm{CO}$, for transfer to the $\mathrm{CO}$ reduction process without contamination with cabin $N$, as characteristic of the SDAS

6. The CO. removal rate can be automatically varled up or down to allow handling variations in loads: not possible with the SDAS

7. Avoids the conipressor. its noise, and $\mathrm{CO}$ accumuiator as needed by the SDAS.

8. The subsystem is maintainable at the individuai electrochemical cell level which provides for greater reliability le.g. a four-person system consists of 24 cells with each one of these maintainable).

9. Adapts to the integrated $0 . \mathrm{H}_{2}$ and water concepl for Space Station simplification. cost reduction and flexiblity (discussed in more detail below).

\section{$\mathrm{CO}_{2}$ Reduction Processes}

The Bosch /14. 15/ and Sabatier / 16/ processes have been described previously. The 80 sch $\mathrm{CO}_{\text {, reduction process reduces }}$ $\mathrm{CO}_{2}$ with $\mathrm{H}$, to form solid carbon and water. Complete conversion is obtained by recycling the process gases with continuous deposition of carbon and removal of water. The carbon is collected in an expendable cartridge ( see Figure 5) contained in the Bosch reactor. The Bosch process requires a small quantity of expendables (see Table 10)

The Sabatier process reduces $\mathrm{CO}_{2}$ with $\mathrm{H}_{2}$ to form $\mathrm{CH}_{4}$. Complete conversion $(>99 \%)$ is obtained in one pass through the Sabatier reactor (see Figure 6). The water is condensed and the exhaust gases. primarily $\mathrm{CH}_{4}$ and unreacted $\mathrm{CO}_{2}$, are vented overboard. The Sabatier process requires no expendables.

\section{Static Feed Electrolyser (SFE)}

The static feed /17. 18/ and solid polymer electrolyte / 19/ water electrolysis systems have been described elsewhere. The static 
TABLE 9 Electrochemical $\mathrm{CO}_{2}$ Concentrator Charts

\begin{tabular}{|c|c|c|c|c|c|c|c|c|c|c|c|}
\hline \multirow{2}{*}{$\begin{array}{l}\text { Model } \\
\text { No. }\end{array}$} & \multicolumn{2}{|c|}{ Cadacity, People on } & \multirow{2}{*}{$\begin{array}{c}\text { Weight. } \\
\text { Lb }\end{array}$} & \multirow{2}{*}{$\begin{array}{c}\text { Volume. } \\
\mathrm{Fi}^{3}\end{array}$} & \multicolumn{3}{|c|}{ Dimensions in } & \multicolumn{2}{|c|}{ Power.W } & \multirow{2}{*}{$\begin{array}{c}\text { Heat } \\
\text { Load. W }\end{array}$} & \multirow{2}{*}{$\begin{array}{l}\text { No. of } \\
\text { Cells }\end{array}$} \\
\hline & $3 m m \mathrm{Hg}$ & $12 \mathrm{~mm} \mathrm{Hg}$ & & & $\mathrm{HI}$ & wd & $\operatorname{Ln}$ & DC Out & $A C \ln$ & & \\
\hline CS. 4 & 4 & 8 & 86 & 2.5 & 20.6 & 15.5 & 13.5 & 100 & 50 & 245 & 24 \\
\hline CS. 6 & 6 & 12 & 110 & 3.1 & 25.4 & 15.5 & 13.5 & 160 & 80 & 364 & 36 \\
\hline CS-8 & 8 & 16 & 134 & 3.7 & 30.2 & 15.5 & 13.5 & 220 & 80 & 450 & 48 \\
\hline CS. 12 & 12 & 24 & 182 & 4.8 & 39.8 & 15.5 & 13.5 & 340 & 80 & 626 & 72 \\
\hline
\end{tabular}

a Based on 220 it $\mathrm{CO}_{2} /$ toerson-day and all sizes for the norrunal partial $\mathrm{CO}_{2}$ pressure of $3.0 \mathrm{~mm} \mathrm{Hg}$.

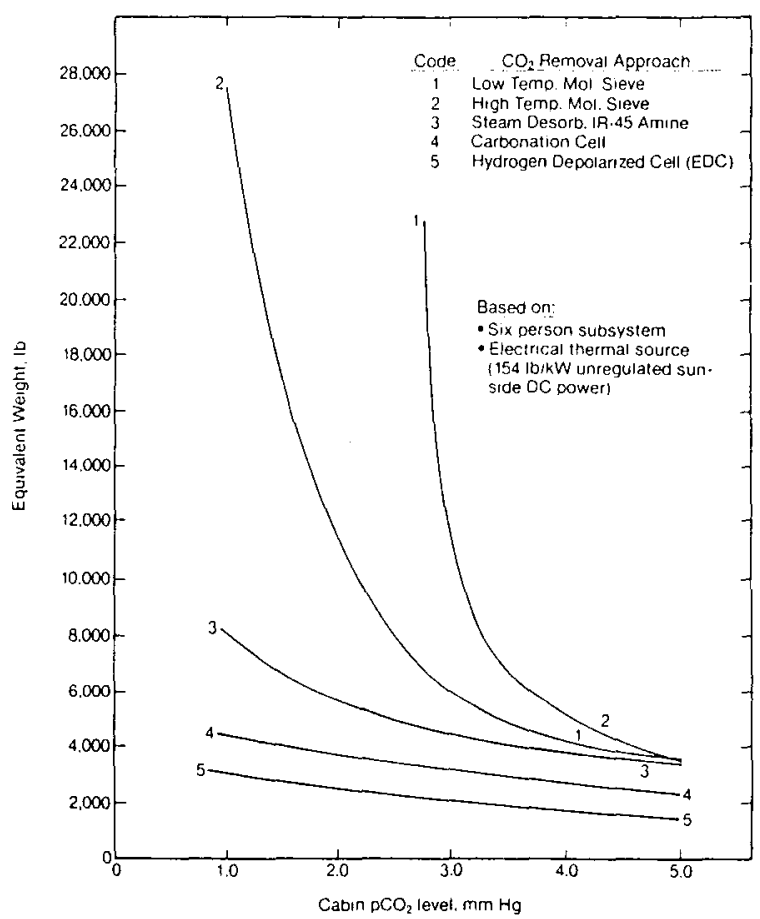

Fig. 4. Space Station Prototype $\mathrm{CO}_{2}$ Concentrator Study Results

TABLE 10 Bosch $\mathrm{CO}_{2}$ Reduction Expendables (Four People, 90 Days)

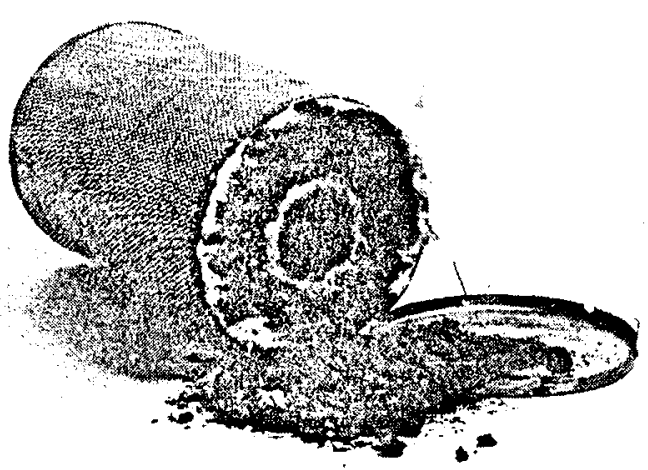

Fig. 5. Bosch $\mathrm{CO}_{2}$ Reduction Cartridge with Carbon Collected

\begin{tabular}{|c|c|c|}
\hline Elements & Wt. & Vol. \\
\hline Canister, blanket filter and catalyst & 66.6 & 8.47 \\
\hline Filter blanket and catalyst only & 21.7 & 2.46 \\
\hline Catalyst only & 5.9 & 0.38 \\
\hline Carbon Formed & 216 & $6.96^{(a)}$ \\
\hline Returned canister & 292.6 & 8.47 \\
\hline
\end{tabular}

(a) Assumes a tinal packing density of $31 \mathrm{lb} / \mathrm{t}^{3}$ 


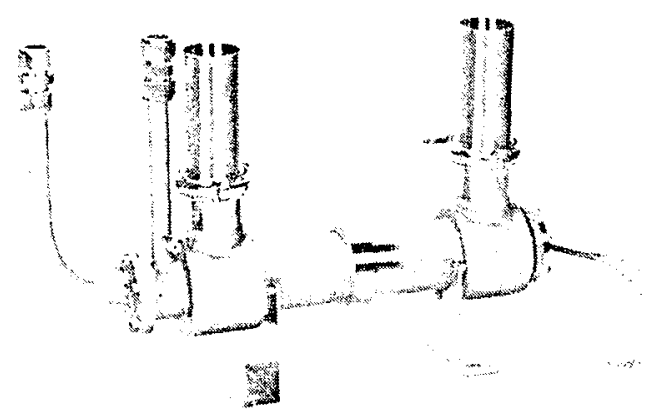

Fig. 6. Sabatier $\mathrm{CO}_{2}$ Reduction Reactor

feed has evoived into a simple. !ow-cost. reliable system. it has been desianed for the Space Station ECLSS and as a major comoonent of a Regenerative Fuel Ceil System (RFCS) aoproach to energy storage. Currently. more than 30.000 hours have been accumulated on several static feed units under endurance / performance test programs. Figure 7 shows a three-person static teed electrolysis subsystem for ECLSS application.

The static feed approach offers many advantages over other water electrolysis approacnes for space application, including:

1. Fewer combonents for less weight. power and volume.

2. Less complex because the gas/liquid separator of the acid electrolyte. solid polymer subsystem is eliminated.

3. Less costly materials of construction. possible because an alkaline versus an acid electrolyte is used.

4. Less sensitive to quality of feed water because the liquid water remains isolated trom the electrolysis cell itself. i.e.. internally generates "distilled" water rather than circulating the feed water over the electrodes as with the solid polymer approach.

5. A higher electrolysis operating efficiency at a given set of operating conditions (temperature, pressure and current density) because of the electrodes and alkaline electrolyte used.
6. Avoids the need for additional heating and cooling characteristic of the solid polymer s iecirculating water feed system.

The static feed eiectrolyzer is also adaptable to operating pressures from ambient to over $1,000 \mathrm{Dsig}$.

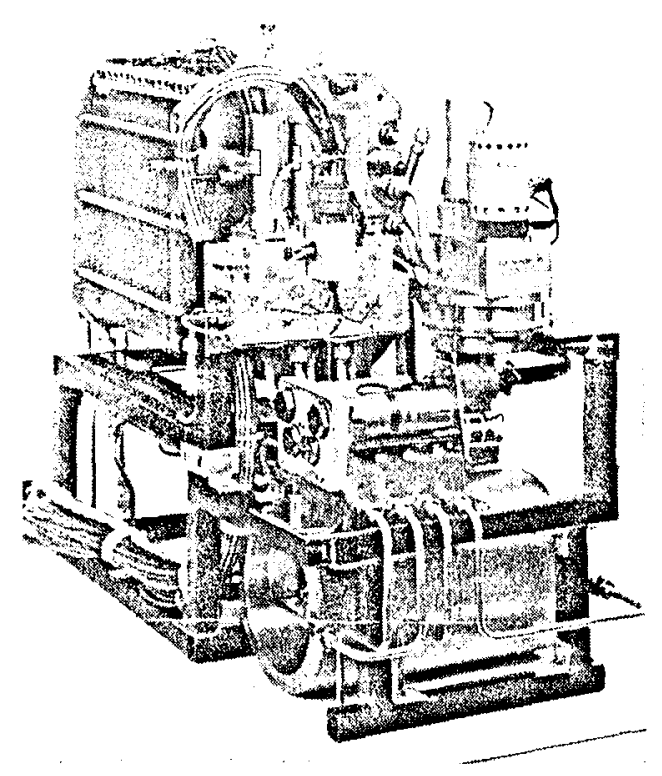

Fig. 7. Static Feed Water Electrolysis Subsystem (SFE)

\section{Water Reclamation}

Water reclamation aboard a Space Station is of equal imoortance to air revitalization. Water reclamation involves processes to reclaim water from wastewater sources. Various processes, including phase change and filtration, have been investigated for these applications. Fitration processes are less developed than the phase change processes for water reclamation.

Figure 8 presents an overview of the water uses and reclamation processes. which functional groups provide water to be recovered

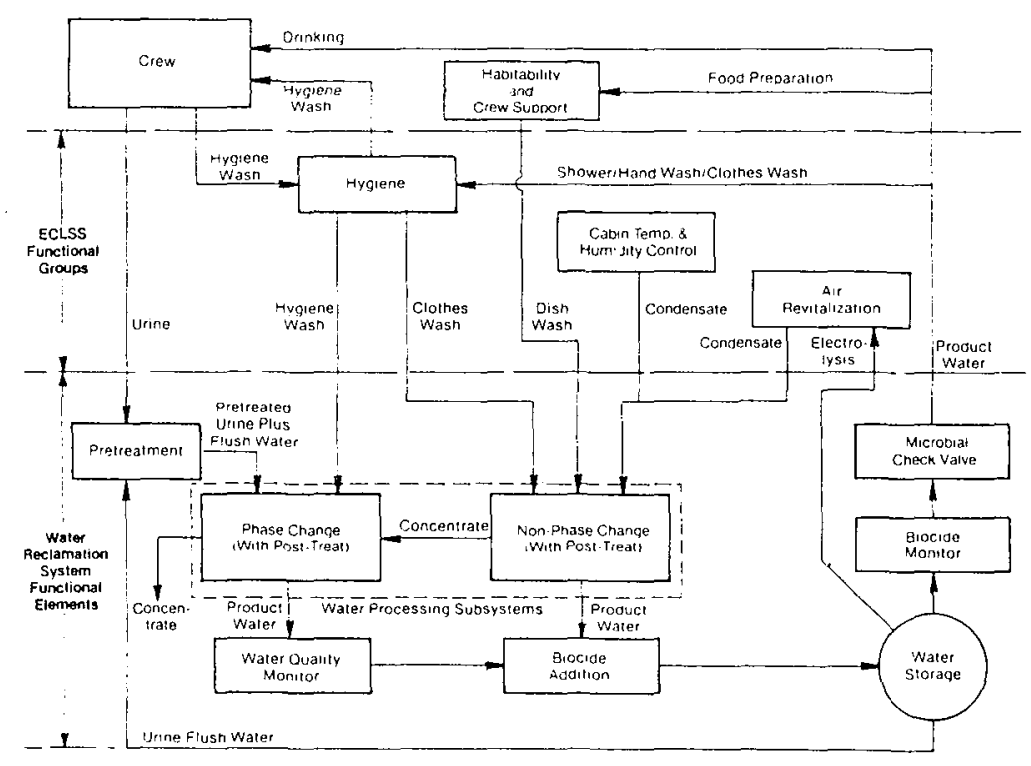

Fig. 8. Water Reclamation/Use Process Overview 
and what are the elements of the water reclamation system. Two major water processing techniques have been considered for space use: phase change and filtration. Table 11 summarizes whicn process is considered most applicable to which waste water source. The goal. however, would be to have one process handle ail the water. The preferred process would be the phase change one because of its attractiveness for providing a better quality potable water.

TABIE 11 Space Station Wastewater Sources and Projected Processing Techniques

\begin{tabular}{ll}
\multicolumn{1}{c}{ Wastewater Source } & Water Processing T \\
Filtration & \\
Hand Wash Water & \\
Shower Water & \\
Urinal Flush Water & \\
Urine & \\
EVA Wastewater & $\mathrm{X}$ \\
Perspiration and Respiration & $\mathrm{X}$ \\
Hygiene Latent Water & $\mathrm{X}$ \\
Food Preparation Latent Water & $\mathrm{X}$ \\
Experiments Latent Water & $\mathrm{X}$ \\
Laundry Latent Water & $\mathrm{X}$ \\
Clothing Wash Water & $\mathrm{X}$ \\
Dishes Wash Water &
\end{tabular}

\section{Phase Change Processes}

Many phase change processes have been considered for spacecraft water reclamation. The two currently under active develooment include the Vapor Compression Distillation (VCD) process which is shown conceptually in Figure 9 . Figure 10 is a photograph of a $72 \mathrm{lb} /$ day VCD subsystem. The recovery of latent heat in the VCD process is accomplished by compressing the vapor to raise its saturation temperature and then condensing the vapor on a surface which is in thermal contact with the evaporator $120 \%$

The alternative is the thermoelectric / membrane process which is shown conceptually in Figure 11. This concept / $21 /$ recovers the latent heat of condensation and transfers this heat to the evaporator via a thermoelectric heat pump. Wastewater is heated to approximately $150^{\circ} \mathrm{F}$ in the thermal electric heat exchanger and the heated wastewater pumped through a hollow fiber membrane evaporator module. The exterior of the module tubes is exposed to reduced pressure. and water evaporates from the tube surface and is condensed on a chilled porous plate surface in thermal contact with the cold junction surtaces of the thermoelectric heat exchanger.

The above mentioned water reclamation processes typically require pretreatment and post-treatment with expendable

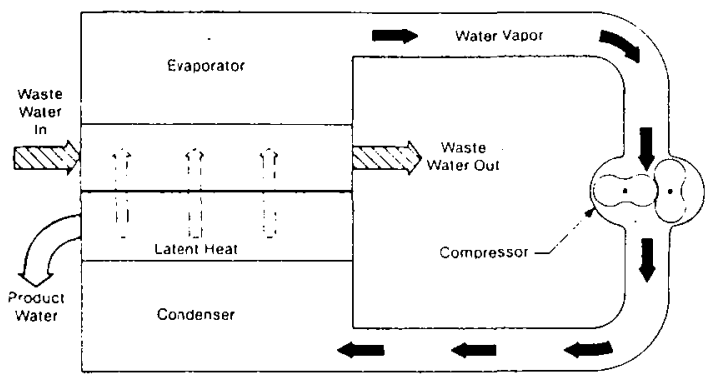

Fig. 9. Vapor Compression Distillation Concept chemicals. A vapor - phase catalytic ammonia-removal process is under develooment which offers the potential advantage of avoiding these expendables / 22/.

\section{Automated Control/Monitor Instrumentation (C/M I)}

The ECLSS process liardware requires instrumentation to:

- Control and monitor the process functiuons:

- Provide safety for personnel and equipment including fault diagnostics and backup control functions:

- Operate the equipment in a manner that increases reliability and avoids need for maintenance or simplifies it if it is required: and

- Operate the equipment under optimized conditions which can. therefore, reduce power, werght. volume. etc.

NASA has developed two C/M I series as shown in Figure 12. The first series. known as the 100 Series, used a minicomputer for process control and monitor, and incorporated a simulated Space Station Command Center in the area of operator/system interfaces (visual, audio and touch). The second series, known as the 200 Series, used a microcomputer for process control and monitor. but replaced the simulated Command Center. with a data link to a remote terminal. The 100 Series, on the lett of Figure 12 , is approximately $29 \times 22 \times 21$ in, the 200 Series, on the right, is $7.4 \times 15.6 \times 15.4$ in

These computerized $\mathrm{C} / \mathrm{M}$ I Series demonstrated the feasibility of a generic approach to Space Station System C/M I requirements including the ECLSS. The 100 Series was designed, for example. for operation with nine major subsystems. The 200 Series was designed for operation with 12 subsystems. The next generation, under develooment by NASA, will employ a generic microcomputer with generic software plus subsystem unique sottware, generic signal conditioning and dedicated actuator signal conditioning.

\section{Water Electrolysis - A Space Station Utiiity}

The merits of a Space Station based on water electrolysis as a station utility was identified over ten years ago $/ 4 /$. The objective is to achieve development commonality to reduce life cycle costs. The $\mathrm{O}_{2}, \mathrm{H}_{2}$ and water are common fluids for:

1. Electrochemical $\mathrm{CO}_{2}$ removal (EDC).

2. 0 , generation for metabolic use and leakage makeup.

3. Potable water for crew consumption and evaporator cooling,

4. Energy storage through a regenerative fuel cell system. and

5. Clean attitude control propellants.

The integrated $\mathrm{O}_{2}, \mathrm{H}_{2}$ and water concept offers the future growth potential of providing in-flight generation of propellants for use by Orbital Transfer Vehicles as well as process reactants for special uses such as manufacturing process atmospheres. Figure 13

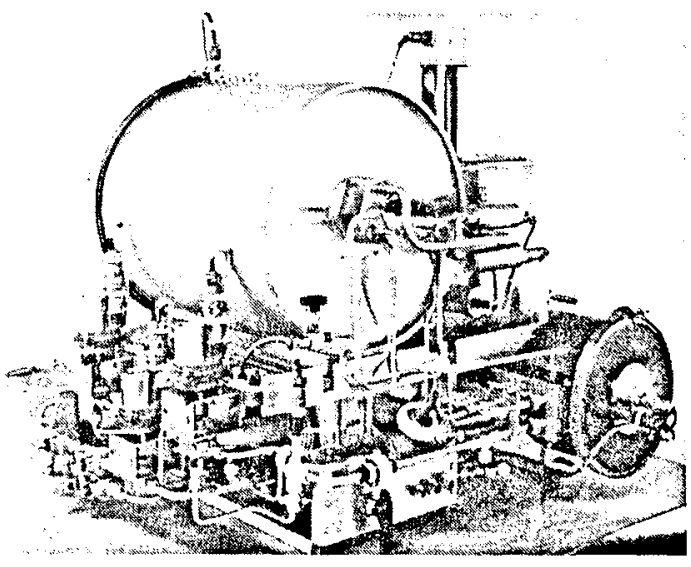

Fig. 10. Preprototype Vapor Compression Discillation Subsystem 


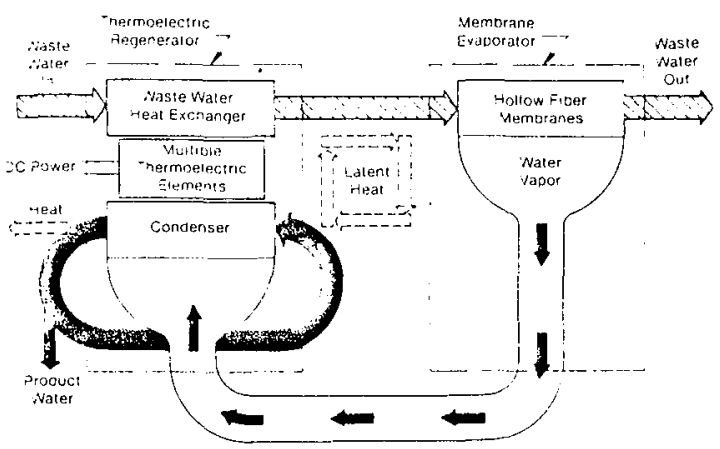

Fig. 11. Thermoelectric/Membrane Evaporator Concept

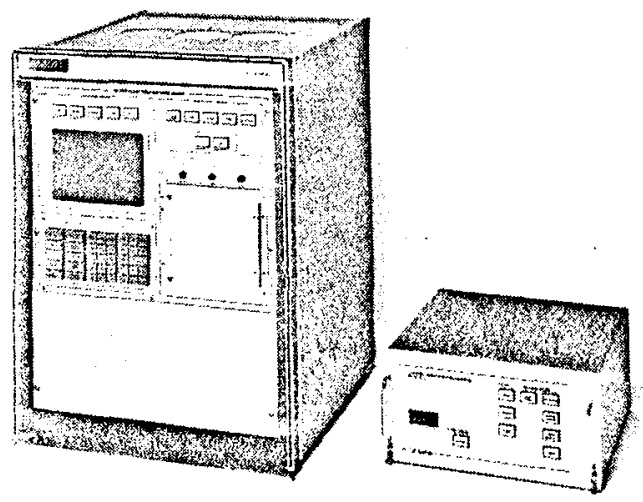

Fig. 12. Series 100 and 200 Computerized Control/Monitor instrumentation

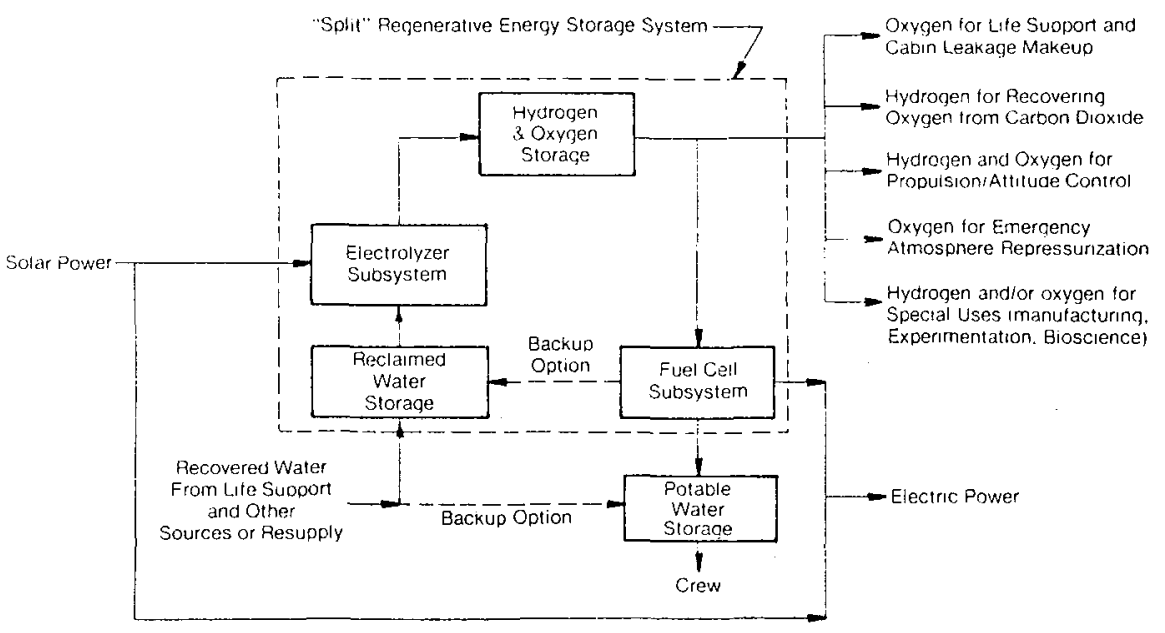

Fig. 13. Water Electrolysis - A Space Station Utility

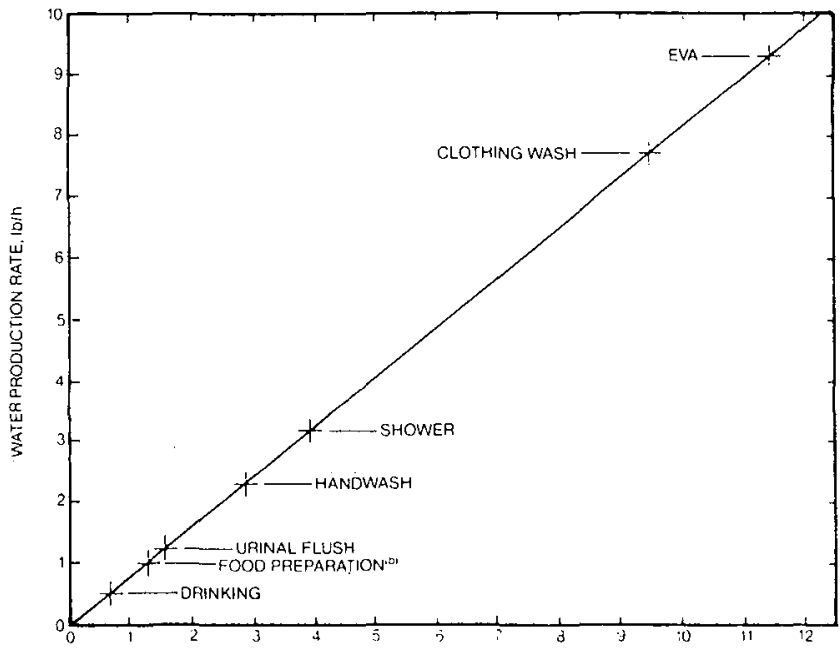

FUEL CELL POWER OUTPUT'A' $\mathrm{kW}$

(a) Lased on Shuttle Oroter Equivalent Fues Ce:l Hardware operating at 091 ViCell. 200 ASF and $180 F$ bicited use rates are cumulative and incluce all lower use rates

Fig. 14. Water Production and Use Rate for Four Persons Versus Fued Cell Power Output 


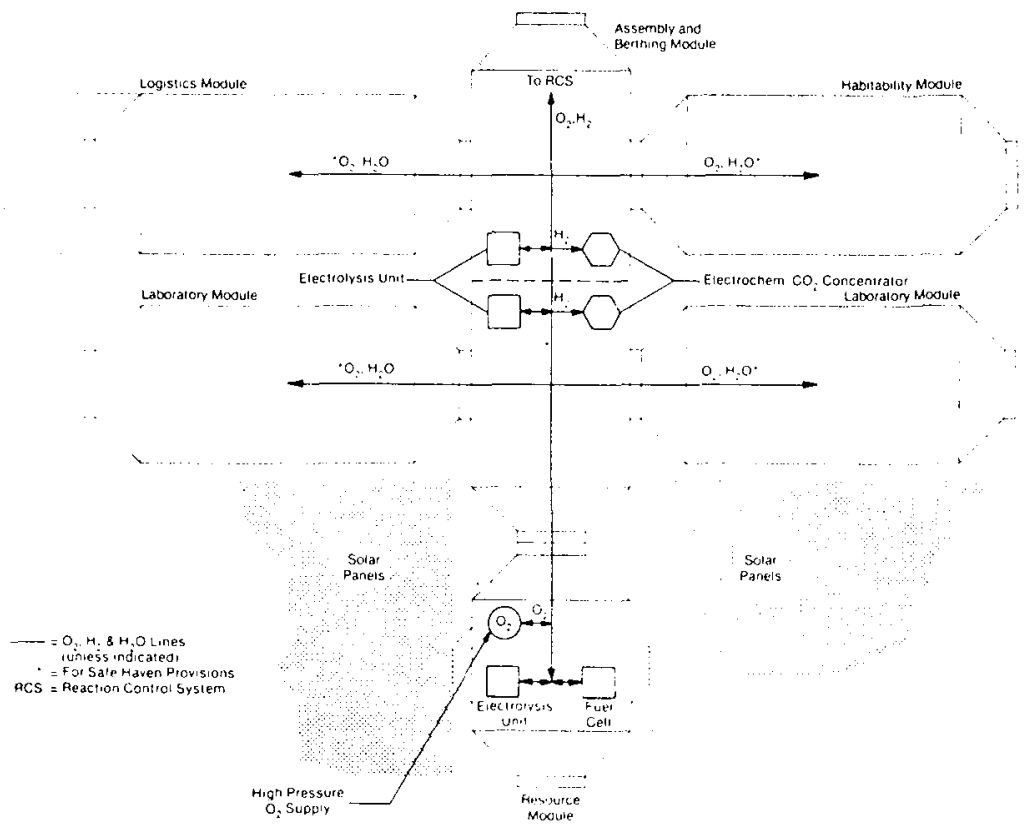

Fig. 15. Integrated $\mathrm{O}_{2}, \mathrm{H}_{2}$ and Water Distribution

illustrates the concepts. It shows the use of fuel cells for dark side operation and provides an adced benefit in that the product water is a flight proven source of potable water for the crew. Reclaimed water is then used directly 10 provide makeup water for the electrolyzer. which is a possibie when using the static feed (SFE) concept. Figure 14 relates water production and use rates versus fuel cell power output for a four-person ECLSS.

Figure 15 refiects the distribution of such an integrated $\mathrm{O}_{2}, \mathrm{H}_{2}$ and water distribution system aboard a pathtinding architecture for the Space Station.

\section{CONCLUSIONS}

The need and requirements of a Space Station have been reviewed. The elements of an ECLSS have been cited including performance requirements. average design loads and fluid interfaces. Open versus closed loop approaches to ECLSS have been quantified. Specific regenerative ECLSS technology has been discussed with some comparisons madse between alternative approaches. The status of control and monitor instrumentation was indicated. The benefits of water electroysis as a Space Station utility, which results in a Space Station based on an integrated $\mathrm{O}_{2}, \mathrm{H}_{2}$ and water for common fluids. was reviewed.

\section{ACKNOWLEDGEMENT}

The authors wish to acknowledge the support of NASA and Life Systems. Inc in the development of regenerative ECLSS technology. Specific acknowledgement is given to the following NASA technical personnel contributing to the technology base upon which this article was prepared: Nick Lance. Don Price. Frank Samonski and Dr. Ted Wydeven.

\section{REFERENCES}

1. Lyndon B. Johnson Space Center. Space Station System Requirements and Characteristics. Book 3. (October 1982)

2. George C. Marshali Space Flight Center. Space Station Systems Definition, Book 5, (October 1982).

3. Lyndon B. Johnson Space Center. Space Station Systems Requirements and Characteristics. Book 3. p. 67. (1982)

4. North American Rockwell. Modular Space Station. Phase B Extension. Preliminary System Design. NAS9-9953. (January 1972 ).

5. McDonneli Douglas Co. Space Station Preliminary Design. Preliminary Systems Design Data, Volume 1. Book 3. NAS8-25140. Crew Systems, (July 1970).

6. General Dynamics. Study for Basic Subsystem Module Preliminary Detinition. Final Report. NAS9-6796, (1973).

7. Boeing Aerospace Company. Space Operations Center, NAS9-16151. (January 1982).

8. Lyndon B. Johnson Space Center. Space Station Systems. Requirements and Characteristics, Book 3, p. 56, (August 1982)

9. Lyndon B. Johnson Space Center. Space Operations Center. A Concept Analysis. JSC-16277. Volume 1. (November 1979).

10. F.H. Schubert, T.M. Hallick and E.P. Koszenski, Advanced Electrochemical Depolarized Concentrator Cell Development, Final Report. Contract NAS2-10204. NASA CR-166141, TR-379-4, Life Systems. Inc., Cleveland, OH, (December 1981)

11. N. Lance. Jr. and F.H. Schubert. Regenerable CO, Collection for Spacecratt Application. ASME Paper No. 81-ENAs-28. San Francisco. CA. (July 1981)

12. D.B. Heppner and F.H. Schubert, Electrochemical and Steam Desorbed Amine $\mathrm{CO}_{2}$ Concentration: Subsystem Comparison, SAE Paper No. 831120. San Francisco, CA. (July 1983)

13. Hamilton Standard, Space Station Prototype ETC/LSS, System Level Trace Studies, Document 11, (July 1970).

14. D.B. Heppner, D.C. Clark, T.M. Hallick and P.D. Quattrone, Bosch, An Alternate $\mathrm{CO}_{2}$ Reduction Technology. ASME Paper No. 79-ENAs-32, San Francisco CA. (July 1979)

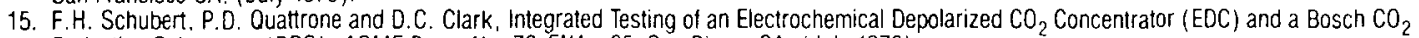
Reduction Subsystem (BRS), ASME Paper No. 76-ENAs-35, San Diego, CA, (July 1976)

16. P.D. Quattrone, Spacecratt Oxygen Recovery System, Astronautica Acta, Vol. 18, pp. 261-271, Pergamon Press, (1973).

17. F.H. Schubert, J.B. Lance and T.M. Hallick, Development of a Static Feed Water Electrolysis System, Final Report, Contract NAS2-10306 TR-404-4, Life Systems, Inc., Cleveland, OH, (January 1982).

18. F.H. Schubert, K.A. Burke and P.D. Quattrone, Oxygen Generation Subsystem for Spacecraft, ASME Paper No. 81-ENAS-40, San Francisco, CA (July 1981)

19. R.B. Martin and A.C. Erickson, Development Status of a Preprototype Water Electrolysis Subsystem, ASME Paper No. 81-ENAS-9, San Francisco. CA, (March 1981).

20. C.D. Thompson, G.S. Ellis and F.H. Schubert, Preprototype Vapor Compression Distillation Subsystem Development, Paper No. 81-ENAS-25. San Francisco, CA (July 1981).

21. H.E. Winkler and G.J. Roebelen, Jr., Development of Preprototype Thermoelectric Integrated Membrane Evaporation Subsystem tor Water Recovery, Paper No. 80-ENAs-46, Intersociety Conterence on Environmental System, San Diego, CA, (July 1980)

22. P. Budininkas, Removal of Ammonia from Urine Vapor by a Dual-Catalyst System, ASME Paper No. 77-ENAS-48, San FrancisCo, CA, (July 1977). 